University of Nebraska - Lincoln

DigitalCommons@University of Nebraska - Lincoln

Agronomy \& Horticulture -- Faculty Publications

Agronomy and Horticulture Department

1998

\title{
Mycorrhizal Colonization and Nutrition of Wheat and Sweet Corn Grown in Manure-Treated and Untreated Topsoil and Subsoil
}

\author{
David D. Tarkalson \\ Agronomy and Horticulture Department, Brigham Young University, Provo, UT, \\ david.tarkalson@ars.usda.gov \\ Von D. Jolley \\ Agronomy and Horticulture Department, Brigham Young University, Provo, UT \\ Charles W. Robbins \\ USDA, ARS \\ Richard E. Terry \\ Agronomy and Horticulture Department, Brigham Young University, Provo, UT
}

Follow this and additional works at: https://digitalcommons.unl.edu/agronomyfacpub

Part of the Plant Sciences Commons

Tarkalson, David D.; Jolley, Von D.; Robbins, Charles W.; and Terry, Richard E., "Mycorrhizal Colonization and Nutrition of Wheat and Sweet Corn Grown in Manure-Treated and Untreated Topsoil and Subsoil" (1998). Agronomy \& Horticulture -- Faculty Publications. 325.

https://digitalcommons.unl.edu/agronomyfacpub/325

This Article is brought to you for free and open access by the Agronomy and Horticulture Department at DigitalCommons@University of Nebraska - Lincoln. It has been accepted for inclusion in Agronomy \& Horticulture -Faculty Publications by an authorized administrator of DigitalCommons@University of Nebraska - Lincoln. 


\title{
Mycorrhizal Colonization and Nutrition of Wheat and Sweet Corn Grown in Manure- Treated and Untreated Topsoil and Subsoil
}

\author{
David D. Tarkalson, ${ }^{a}$ Von D. Jolley, ${ }^{\mathrm{a}}$ Charles W. Robbins, ${ }^{\mathrm{b}}$ and \\ Richard E. Terry ${ }^{\mathrm{a}}$ \\ agronomy and Horticulture Department, Brigham Young University, Provo, \\ UT 84602 \\ ${ }^{\mathrm{b}} U S D A, A R S$, Northwest Irrigation and Soils Research Laboratory, Kimberly, \\ ID 83341
}

\begin{abstract}
Dry bean yields (Phaseolus vulgaris L.) were raised to similar levels as the topsoil by manure application to eroded or leveled Portneuf silt loam soil (coarse-silty mixed mesic Durixerollic Calciorthid). Only soil organic matter and zinc $(\mathrm{Zn})$ content of leaf tissue were correlated with improved yields. Manure application increased mycorrhizal colonization and $\mathrm{Zn}$ uptake in pot experiments with dry bean which would explain the increased yields in the field. A field study was conducted to see if similar effects of manure and mycorrhizal colonization could be observed in field grown spring wheat (Triticum aestivum L.) and sweet corn (Zea mays L.). This study was conducted on existing experiments established in the spring of 1991 at the USDA-ARS farm in Kimberly, Idaho, to study crop rotation/organic matter amendment treatments on exposed subsoils and focused on mycorrhizal colonization as related to topsoils and subsoils treated with conventional fertilizer (untreated) or dairy
\end{abstract}


manure. Mycorrhizal root colonization was higher with untreated than with manure-treated wheat and sweet corn. Root colonization was also higher in subsoil than in topsoil for wheat, but there were no differences between soils for sweet corn. Shoot $\mathrm{Zn}$ and manganese $(\mathrm{Mn})$ concentrations generally increased with increased root colonization for both species (except between soils with corn Mn contents). Wheat shoot potassium (K) concentration was increased by manure application, but the affect declined with time, was the opposite of colonization and was not observed with sweet corn. Phosphorus $(\mathrm{P})$, calcium $(\mathrm{Ca})$, magnesium $(\mathrm{Mg})$, iron $(\mathrm{Fe})$, and copper $(\mathrm{Cu})$ concentrations either were not influenced or were erratically affected by mycorrhizal colonization. Yields of wheat were highest for manure-treated subsoil and topsoil compared to untreated soils. Mycorrhizal colonization was different between conventional and manure-treated soils and between topsoil and subsoil and these differences increased $\mathrm{Zn}$ and $\mathrm{Mn}$ uptake, but they did not explain the improvement in wheat yields obtained with manure application.

\section{INTRODUCTION}

Land leveling and irrigation-induced topsoil erosion of silt loam soils in south central Idaho have resulted in reduced yields on about 800,000 ha. Because crop productivity on subsoil is negatively affected, successful restoration of dry bean productivity on subsoils of a Portneuf silt loam using manure was a major advance (Robbins et al., 1997). Factors which correlated with the improved dry bean yields were soil organic matter and plant zinc content. Dry bean grown in manure-amended Portneuf silt loam soil in greenhouse pots showed increased mycorrhizal colonization compared to unmanured subsoil and this related to increased uptake of $\mathrm{Zn}$ (Tarkalson et al., 1998). Thus, increased mycorrhizal colonization offered an explanation for improved yields and $\mathrm{Zn}$ uptake in dry bean in manured soils. Other factors increasing $\mathrm{Zn}$ solubilization could be short-chained organic molecules, or improved bulk density and root development.

Mycorrhizae have reportedly increased nutrient uptake, salinity tolerance, drought tolerance, water uptake, root disease resistance, and photosynthesis (Srivastava et al., 1996; Sharma et al., 1994). Mycorrhizal extension of the plant root surface facilitates potential uptake and translocation of $P$, nitrogen $(N), K, C a$, sulfur (S), Cu, molybdenum (Mo), and Zn (Srivastava et al., 1996; Singer and Munns, 1987; Azcon-Aguilar and Barea, 1992; Sharma and Srivastava, 1991; Sharma et al., 1994; Lambert and Weidensaul, 1991; Burkert and Robson, 1994; Hamilton et al., 1993; Swaminathan and Verma, 1979; Frey and Ellis, 1997). Because Zn availability can be low in neutral to alkaline soils due to adsorption on aluminum (Al) and $\mathrm{Fe}$ oxides, clay minerals, organic matter, and $\mathrm{CaCO}_{3}$ (Tisdale et al., 1993), mycorrhizae in these soils could potentially benefit plants. High fertilizer application generally decreases the mycorrhizal impact on nutrient uptake (Ellis et al., 1992). 
The additions of manure and other organic matter to soils usually benefit crop yields by improved aeration, water penetration, water-holding capacity, soil structure, cation exchange capacity, soil buffering, microbial activity, or nutrient availability. However, the relationship between mycorrhizae and soil organic matter is unclear. Some research shows that soil organic matter increases the colonization of roots by arbuscular mycorrhizal fungi (AMF) (Mosse, 1959; Ishac et al., 1986) and others show decreases (Ellis et al., 1992; Brechelt, 1987). Hepper and Warner (1983) showed that mycorrhizal hyphae grew saprophitically in the soil and that organic matter stimulated this process. St. John et al. (1983) demonstrated that mycorrhizal hyphae increased in length and branching due to organic matter. Additions of farmyard manures or composts increased root AMF entry points compared to additions of artificial fertilizers (Mosse, 1959). This was presumably a result of extended susceptibility of roots to AMF colonization due to manure affects on the root physiology. Mosse (1959) observed that "The fungi may be capable of a more extensive extra-matrical development in composts containing a high proportion of organic matter." Increased breakdown of organic matter by the mycorrhizal association was also noted. However, Ellis et al. (1992) found that AMF colonization was reduced with manure additions when compared to other fertilizer applications with soybean and sorghum. Mycorrhizae tend to develop most extensively under low fertility conditions (Brechelt, 1987). Brechelt (1987) grew Capsicum annuum in soils containing grass mulch, stable manure, and three kinds of compost in varying concentrations and found greatest yield and $P$ uptake in soils containing the lowest additions of manure. High manure treatments led to decreased mycorrhizal efficiencies as a result of high nutrient content of the manures. Organic matter additions that give rise to rich soil microflora may also decrease hyphae growth by increased microbial competition for old fragments of organic matter (St. John et al., 1983; Nicolson, 1959). The root AMF colonization in a sorghum-soybean rotation fertilized with either cattle manure or fertilizer was greatest when neither fertilizer nor manure was applied and lowest when manure was applied (Ellis et al., 1992). Makawi (1982) found that additions of sludge, poultry manure, cow manure, horse manure, and sheep manure decreased total fungal populations in soils compared to a control. Thus, manure applications have the potential to increase or decrease mycorrhizal effects on plants depending on which factors dominate.

Both wheat and corn are known to be mycorrhizal (Buwalda et al., 1985; Mohammad et al., 1995; Kothari et al., 1991) and could potentially benefit from AMF colonization in calcareous soils. Wheat has not been considered highly dependent on mycorrhizae, but research has shown large yield increases due to mycorrhizae under some conditions (Menge, 1983). Because corn is susceptible to Zn deficiency (Shukla, 1987), the establishment of the mycorrhizal relationship could improve its growth.

Our objectives in this study were to determine if (a) mycorrhizal colonization of wheat and sweet corn roots was affected by manure treatment of subsoil and 
topsoil, and (b) mycorrhizal colonization could be related to nutrient uptake and to yield in sweet corn and wheat.

\section{MATERIALS AND METHODS}

Field plots located 2 miles south and 3 miles west of the USDA-ARS Kimberly, ID research station were established to study crop rotation and manure amendment treatment effects on reclamation of exposed subsoils (Robbins et al., 1997). The design of our research was established by the original split block design. Topsoil and subsoil strips established parallel to the field slope were crossed by strips of treatments consisting of manure added in fall of 1994 (manure-treated) and conventional fertilizer with added $\mathrm{Zn}$ (untreated). Wheat and sweet corn were planted parallel to the slope. Spring wheat (Penewawa) was planted March 27, 1997 at a rate of $107 \mathrm{~kg} \mathrm{ha}^{-1}$ and sweet corn (Jubilee) was planted May 13, 1997 at a rate of $19 \mathrm{~kg} \mathrm{ha}^{-1}$. Each crop-soil-amendment treatment was repeated four times. Corn and wheat were under no-till cultivation in 1997. The treatment history of the plots is as follows:

$\underline{1991}$

18 April: conventional subsoil plots received $135 \mathrm{~kg} \mathrm{ha}^{-1} \mathrm{P}$ as treble superphosphate and $245 \mathrm{~kg} \mathrm{ha}^{-1} \mathrm{~N}$ as urea.

19 April: subsoil+manure 1991 plots received $44 \mathrm{Mg} \mathrm{ha}^{-1}$ air-dried dairy manure.

21 May: all plots received $1.7 \mathrm{~kg} \mathrm{ha}^{-1}$ as $\mathrm{Zn}$-EDTA.

2 May: conventional subsoil plots received $101 \mathrm{~kg} \mathrm{ha}^{-1} \mathrm{~N}$ as urea.

17 October: all conventional subsoil plots received $130 \mathrm{~kg} \mathrm{ha}^{-1} \mathrm{P}$ as treble superphosphate.

18 October: subsoil+manure 1991 plots received $93 \mathrm{Mg} \mathrm{ha}^{-1}$ air-dried dairy manure.

1992

No additional fertilizer or amendments added.

1993

14 April: subsoil conventional plots received $112 \mathrm{~kg} \mathrm{ha}^{-1} \mathrm{~N}$ as urea.

1994

15 November: $74 \mathrm{Mg} \mathrm{ha}^{-1}$ air-dried manure was added to additional subsoil and to topsoil plots.

$\underline{1995}$

10 April: the conventional subsoil plots received $168 \mathrm{~kg} \mathrm{ha}^{-1} \mathrm{~N}$ as urea.

$\underline{1996}$

15 March: topsoil and conventional subsoil plots received $8.4 \mathrm{~kg} \mathrm{ha}^{-1}$ as $\mathrm{Zn}$ EDTA. 

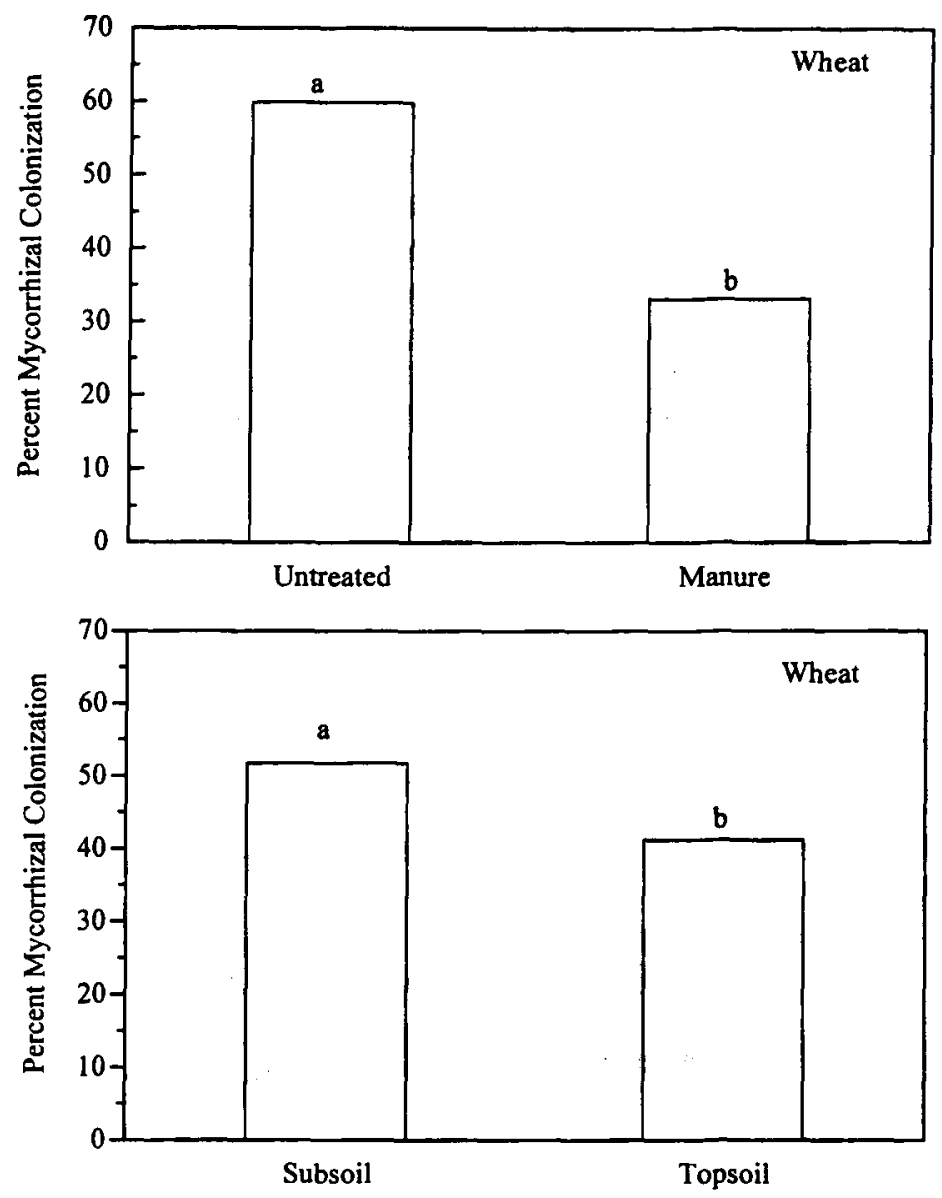

FIGURE 1. Percent mycorrhizal colonization of wheat roots as affected by treatment with or without manure and grown in subsoil or topsoil. There were no significant interactions among treatment, soil, or harvest. Columns with the same letter are not significantly different at the 0.05 level.

Wheat root samples were collected on 13, 20, 27 May, 10, 24 June, and 8, 29 July. Sweet com root samples were collected on 9, 16, 23 June, 7,21 July, and 18 Aug. A soil core sampling device was used to obtain five, $534 \mathrm{~cm}^{3}$ soil cores plot ${ }^{-1}$ at a depth of $15 \mathrm{~cm}$ at each sampling event and the five cores were combined. Root samples were washed with a stream of water to remove soil from the roots the same day as sampled. The roots were cut from the plant tops after washing and a total 
TABLE 1. Concentrations of $\mathrm{Zn}, \mathrm{Mn}, \mathrm{K}, \mathrm{Ca}$, and $\mathrm{P}$ in wheat tops on three harvest dates and related statistics by ANOVA as affected by treatment with or without manure and grown in subsoil or topsoil.

\begin{tabular}{|c|c|c|c|c|c|c|c|c|c|c|}
\hline \multirow[t]{2}{*}{ Nutrient } & \multicolumn{4}{|c|}{ Harvest $(\mathrm{H})$------Treatment $\left(\mathrm{T}^{1}{ }^{1}-\mathrm{-}^{---}\right.$} & \multicolumn{3}{|c|}{-----Soil $(\mathbf{S})^{1}$} & \multicolumn{3}{|c|}{---Interactions--- } \\
\hline & & Untreated & & Manure & Subsoil & & Topsoil & $T * S$ & $\mathrm{~T}^{*} \mathrm{H}$ & $\mathrm{S}^{*} \mathrm{H}$ \\
\hline \multirow[t]{4}{*}{$\overline{\mathrm{Zn}, \mathrm{mg} \mathrm{kg}}$} & 21 May & 59 & NS & 48 & 46 & $*$ & 62 & NS & & \\
\hline & 10 June & 40 & NS & 30 & 32 & NS & 38 & NS & & \\
\hline & 17 July & 30 & NS & 25 & 28 & NS & 27 & NS & & \\
\hline & Mean & 43 & * & .35 & -..--- & & ------ & NS & NS & * \\
\hline \multirow[t]{4}{*}{$\mathrm{Mn}, \mathrm{mg} \mathrm{kg}$} & 21 May & 108 & $* *$ & 71 & 95 & * & 84 & NS & & \\
\hline & 10 June & 64 & $*$ & 50 & 61 & NS & 53 & NS & & \\
\hline & 17 July & 41 & $* *$ & 34 & 42 & $*$ & 33 & NS & & \\
\hline & Mean & --.-- & & $\cdots$ & 66 & NS & 57 & NS & $* *$ & NS \\
\hline \multirow[t]{4}{*}{$\mathrm{K}, \%$} & 21 May & 3.7 & * & 4.2 & 4.0 & NS & 3.9 & NS & & \\
\hline & 10 June & 2.6 & $* *$ & 2.8 & 2.5 & $*$ & 2.9 & NS & & \\
\hline & 17 July & 1.2 & $*$ & 1.4 & 1.3 & NS & 1.3 & NS & & \\
\hline & Mean & -...- & & $-\cdots$ & 2.6 & NS & 2.7 & NS & $*$ & NS \\
\hline \multirow[t]{4}{*}{$\mathrm{Ca}, \%$} & 21 May & 0.44 & * & 0.38 & 0.38 & $*$ & 0.44 & NS & & \\
\hline & 10 June & 0.22 & NS & 0.21 & 0.20 & * & 0.23 & NS & & \\
\hline & 17 July & 0.15 & * & 0.16 & 0.15 & NS & 0.17 & NS & & \\
\hline & Mean & -..-.- & & --..- & 0.24 & * & 0.28 & NS & $* *$ & NS \\
\hline \multirow[t]{4}{*}{$P, \%$} & 21 May & 0.39 & $* *$ & 0.56 & 0.46 & NS & 0.50 & NS & & \\
\hline & 10 June & 0.34 & NS & 0.36 & 0.34 & NS & 0.37 & NS & & \\
\hline & 17 July & 0.23 & NS & 0.24 & 0.24 & NS & 0.22 & NS & & \\
\hline & Mean & --.- & & --.- & -.... & & $\ldots$ & NS & NS & * \\
\hline
\end{tabular}

${ }^{\mathrm{N} S},{ }^{*},{ }^{*}=$ Not significant at 0.05 and significant at 0.05 and 0.01 probability levels, respectively. Means are not presented when the corresponding interaction with harvest, treatment, or soil is significant at the 0.05 level. 
root weight per volume of soil was obtained. The tops were discarded. The roots were mixed and randomly separated into two portions. Half were placed in a preweighed paper bag and weighed. The other half of the roots were placed in a plastic ziplock bag. The roots in the paper bags were placed in a drying oven at $65^{\circ} \mathrm{C}$ and total root weight recorded. The roots placed in the ziplock bags were stored in a freezer to await staining with aniline blue and percent mycorrhizal colonization determination using a point intersection method (Tarkalson et al., 1999; Giovannetti and Mosse, 1980).

Wheat tops were sampled from each plot on 21 May (stooling stage), 10 June (boot stage), and 17 July (soft dough stage). Sweet corn leaves were sampled from each plot on 23 July (beginning tasseling stage) and 4 August (beginning silking stage). Samples were rinsed with water, dried at $65^{\circ} \mathrm{C}$, and ground in preparation for mineral analysis. Zinc, $\mathrm{Fe}, \mathrm{Mn}, \mathrm{Cu}, \mathrm{Ca}, \mathrm{Mg}$, and $\mathrm{K}$ concentrations were determined using dry ashing (AOAC, 1995) and atomic absorption spectrometry. Phosphorus was determined colorimetrically (Watanabe and Olsen, 1965). Yield of wheat grain was obtained in Aug., but sweet corn yields were confounded by excessive weed competition and were not recorded.

\section{Statistical Procedure}

Field data was analyzed as a split-block design using analysis of variance output from SAS. Mean comparisons utilized F-test values from SAS analysis of variance (SAS Institute, 1989).

\section{RESULTS AND DISCUSSION}

\section{Wheat}

There was no treatment by soil interaction with percent colonization of wheat roots so only main treatment effects are reported (Figure 1). Wheat grown on manure-treated soil was colonized at lower rates than on untreated (unmanured) soil and percent colonization on subsoil was significantly higher than on topsoil (Figure 1). Thus, mycorrhizal colonization in wheat decreased due to manure additions contrary to our observations with greenhouse grown dry bean (Tarkalson et al., 1998). This lower colonization of roots in manure-treated soil may be partially attributed to increased microbial competition in the rhizosphere (St. John et al., 1983; Nicolson, 1959). The higher rates of mycorrhizal colonization with subsoil follows commonly held views that lower fertility soils are benefitted more from mycorrhizae than highly fertile soils (Brechelt, 1987).

Wheat top $\mathrm{Zn}$ concentrations for the three harvest times trended lower with manured than untreated soils which were significant for the mean of all harvests (Table 1). These values would correspond to expected levels based on percent mycorrhizal colonization (Table 1, Figure 1). Thus, it appears higher mycorrhizal colonization resulted in enhanced $\mathrm{Zn}$ uptake especially since both root and shoot 
TABLE 2. Mean wheat top concentrations of $\mathrm{Mg}, \mathrm{Fe}, \mathrm{Cu}$, shoot and root weights and yield of wheat grain and related statistics by ANOVA as affected by treatment with or without manure and grown in subsoil or topsoil.

\begin{tabular}{|c|c|c|c|c|c|c|c|c|c|}
\hline \multirow[t]{2}{*}{ Parameter $^{1}$} & \multicolumn{3}{|c|}{-...-Treatment $(T)^{2}$} & \multicolumn{3}{|c|}{-----Soil (S)²---- } & \multicolumn{3}{|c|}{---Interactions--- } \\
\hline & Untreated & & Manure & Subsoil & & Topsoil & $T^{*} S$ & $\mathrm{~T}^{*} \mathrm{H}^{3}$ & $\mathrm{~S}^{*} \mathrm{H}$ \\
\hline$\overline{\mathrm{Mg}, \%}$ & 0.14 & NS & 0.13 & 0.14 & NS & 0.13 & NS & NS & $\overline{\mathrm{NS}}$ \\
\hline $\mathrm{Fe}, \mathrm{mg} \mathrm{kg}^{-1}$ & 157 & NS & 190 & 168 & NS & 178 & NS & NS & NS \\
\hline $\mathrm{Cu}, \mathrm{mg} \mathrm{kg}^{-1}$ & 7.7 & NS & 6.2 & 7.1 & NS & 6.8 & NS & NS & NS \\
\hline $\begin{array}{l}\text { Root weight, } \\
\mathrm{mg} \mathrm{cm}^{-3}\end{array}$ & 0.61 & NS & 0.81 & 0.75 & NS & 0.67 & NS & NS & NS \\
\hline $\begin{array}{l}\text { Shoot } \\
\text { Weight, g }\end{array}$ & 10.8 & NS & 20.0 & 13.4 & NS & 17.4 & NS & $---\cdot$ & ---- \\
\hline Yield, $\mathrm{kg} \mathrm{ha}^{-1}$ & 2803 & * & 4081 & 3342 & NS & 3543 & * & $-\cdots$ & $-\cdots$ \\
\hline
\end{tabular}

'Except for grain yield, values represent the mean of three sampling dates.

${ }^{2} \mathrm{NS},{ }^{*}=$ Not significant at 0.05 and significant at 0.05 probability level, respectively.

${ }^{3} \mathrm{H}$ represents samples harvested on 21 May, 10 June, or 17 July.

weights were unaffected by treatments (Table 2). This enhanced $\mathrm{Zn}$ uptake by mycorrhizae affirms previous observations (Sharma and Srivastava, 1991; Sharma et al., 1994; Frey and Ellis, 1997). The lower $\mathrm{Zn}$ content in the manure treatment could possibly be due to increased adsorption of $\mathrm{Zn}$ on organic matter particles (Tisdale et al., 1993).

Similarly, wheat top Mn concentrations were significantly higher in untreated than in manure-treated soil at each harvest date (Table 1), but the difference declined with time (treatment $\times$ harvest interaction). The trend for $\mathrm{Mn}$ to always be higher for subsoil than topsoil was significant on two of three harvest dates (Table 1). Thus, high Mn concentrations in wheat were associated with higher colonization rates. This is contrary to Kothari et al. (1991) who found mycorrhizal colonized corn to contain less $\mathrm{Mn}$ than uncolonized corn.

When affected by treatment or soil, top tissue concentrations of $K$ and $P$ were negatively related to root mycorrhizal colonization (Table 1, Figure 1). This effect with $P$ is opposite commonly held views that $P$ uptake is enhanced by mycorrhizal colonization (Vivekanandan and Fixen, 1991). However, high P levels often eliminate 

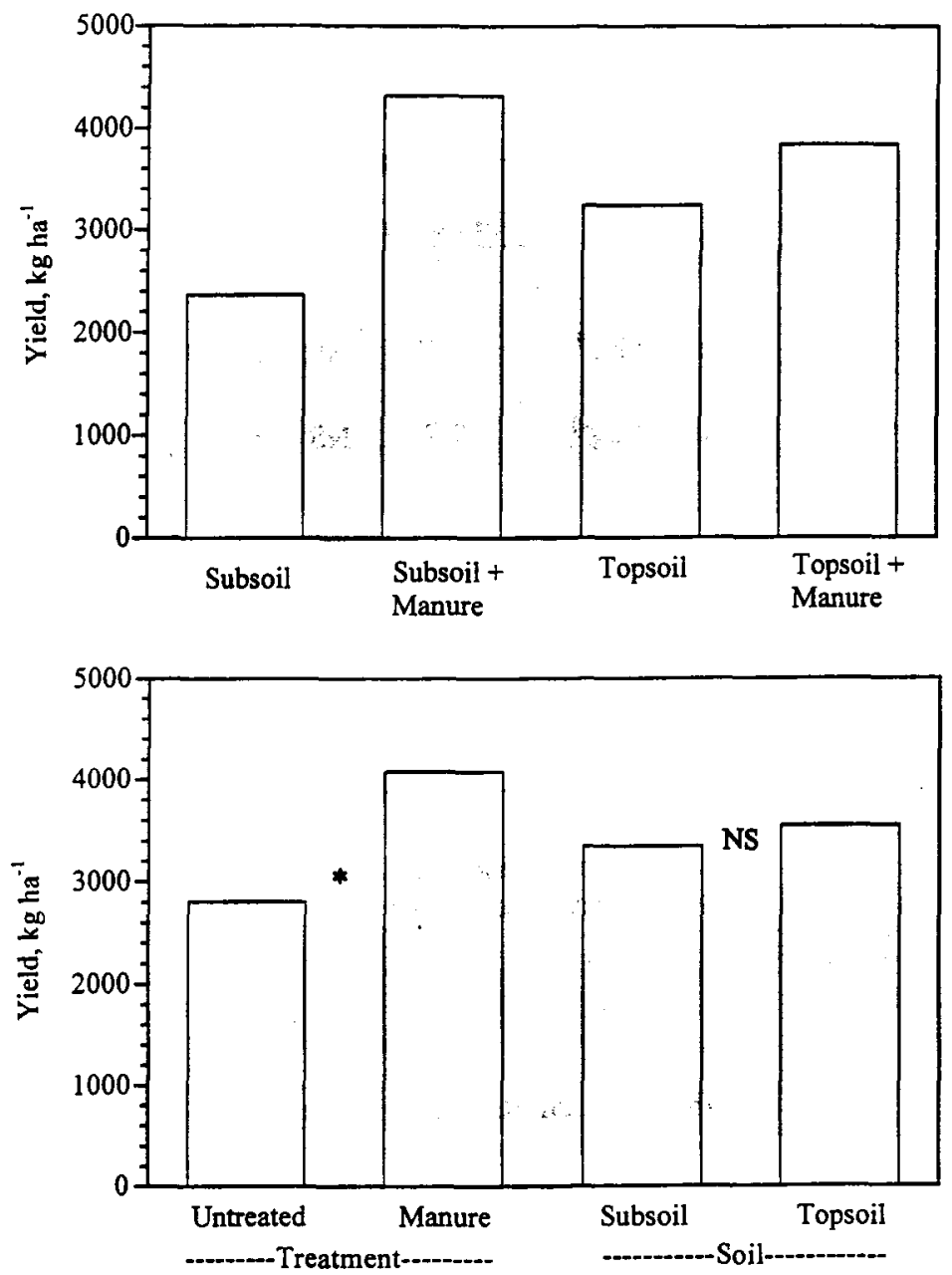

FIGURE 2. Wheat grain yields as affected by treatment with or without manure and grown in subsoil or topsoil. In the bottom graph, ${ }^{*}$ is significant and NS is not significant at the 0.05 level comparing either treatments or soils. There was a significant interaction between treatment and soil at the 0.05 level. In the top graph, the F test for ANOVA for these treatments was significant at the 0.05 level, but mean separation was not possible. 

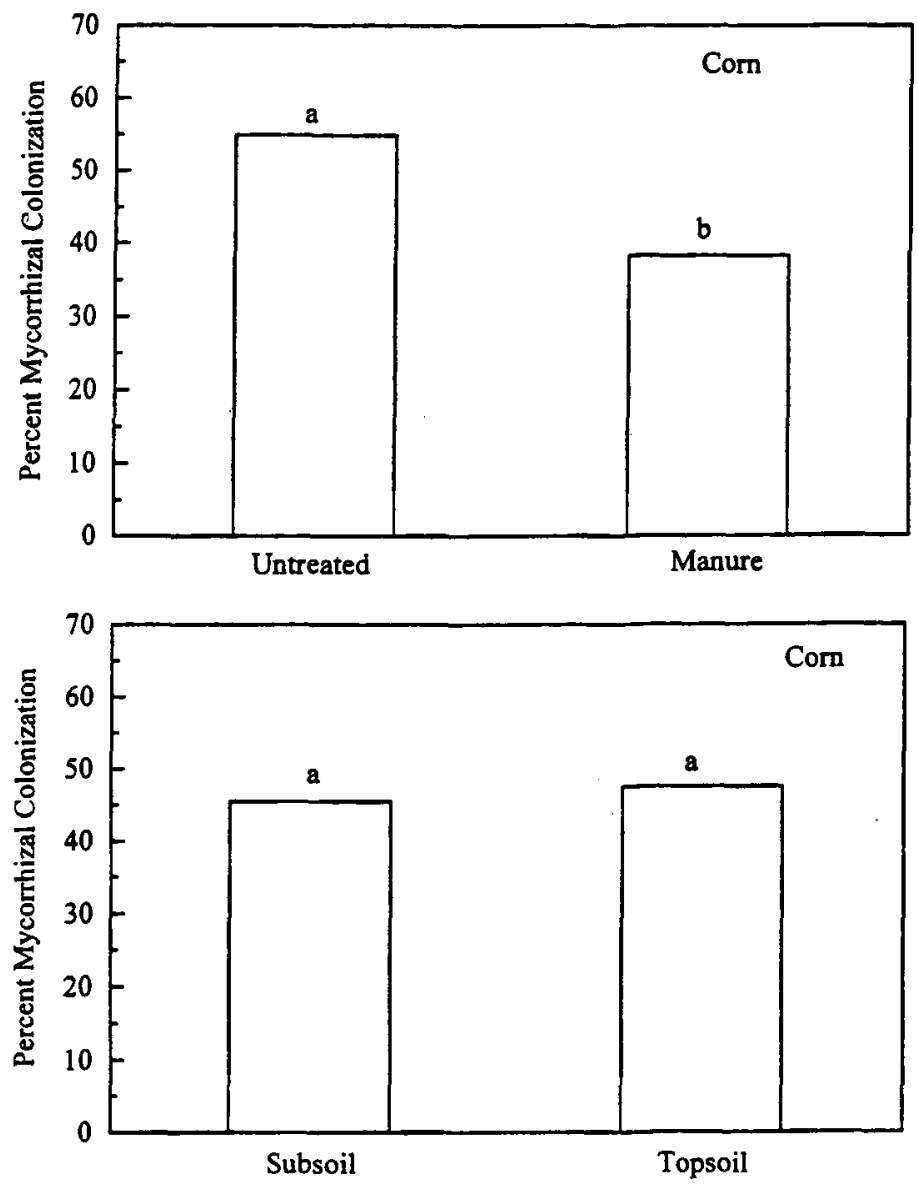

FIGURE 3. Percent mycorrhizal colonization of sweet corn roots as affected by treatment with or without manure and grown in subsoil or topsoil. There were no significant interactions among treatment, soil, or harvest. Columns with the same letter are not significantly different at the 0.05 level.

these effects of mycorrhizae. The average soil $P$ tests in spring 1997 were $22,95,30$, and $142 \mathrm{mg} \mathrm{kg}^{-1}$ for topsoil, topsoil+manure, subsoil, and subsoil+manure. These levels are well above the adequate level for wheat (Kephart and Stark, 1989). Calcium was erratically affected and $\mathrm{Mg}, \mathrm{Cu}, \mathrm{Fe}$, and root and shoot weights were not affected by mycorrhizal colonization (Tables 1 and 2, Figure 1). Thus, uptake of K, $\mathrm{P}, \mathrm{Ca}, \mathrm{Mg}, \mathrm{Cu}$, and $\mathrm{Fe}$ were not related to mycorrhizal colonization in wheat as was observed by Srivastava et al. (1996). 
TABLE 3. Concentrations of $\mathrm{Fe}, \mathrm{Mg}$, and $\mathrm{Ca}$ in com leaves on two harvest dates and related statistics by ANOVA as affected by treatment with or without manure and grown in subsoil or topsoil.

\begin{tabular}{|c|c|c|c|c|c|c|c|c|}
\hline \multirow[t]{2}{*}{ Nutrient } & \multirow[t]{2}{*}{ Harvest $(\mathrm{H})$} & \multicolumn{3}{|c|}{------Treatment (T) ${ }^{1}-\ldots$} & \multicolumn{3}{|c|}{-----Soil (S) ${ }^{1}$-.-.- } & \multirow{2}{*}{$\begin{array}{c}\text { Interactions }{ }^{1} \\
T^{*} S\end{array}$} \\
\hline & & Untreated & & Manure & Subsoil & & Topsoil & \\
\hline \multirow[t]{2}{*}{$\overline{\mathrm{Fe}}, \mathrm{mg} \mathrm{kg}$} & 23 July & 120 & NS & 124 & 114 & NS & 130 & $*$ \\
\hline & 4 Aug. & 86 & NS & 125 & 80 & $*$ & 131 & $*$ \\
\hline \multirow[t]{2}{*}{$\mathrm{Mg}, \%$} & 23 July & 0.40 & ** & 0.34 & 0.40 & $*$ & 0.34 & $* *$ \\
\hline & 4 Aug. & 0.50 & NS & 0.44 & 0.48 & * & 0.45 & NS \\
\hline \multirow[t]{2}{*}{$\mathrm{Ca}, \%$} & 23 July & 0.45 & * & 0.40 & 0.41 & NS & 0.45 & $*$ \\
\hline & 4 Aug. & 0.76 & NS & 0.76 & 0.69 & * & 0.82 & NS \\
\hline
\end{tabular}

'NS, ${ }^{*},{ }^{* *}=$ Not significant at 0.05 and significant at 0.05 and 0.01 probability levels, respectively. Means are not calculated because the corresponding interactions with harvest, treatment, or soil is significant at the 0.05 level.

Wheat yield increases were associated with manure additions to the soils (Figure 2 , bottom). There were no significant differences between topsoil and subsoil wheat yields; however, a soil by treatment interaction was observed. In untreated soils the topsoil produced higher yields than subsoil, but in manured soils the yields of subsoil and topsoil were similar (Figure 2, top). Thus, manure additions to subsoils improved wheat yields comparable to topsoil as was observed in dry bean (Robbins et al., 1997). Increased yields in wheat were not related to mycorrhizal colonization and the results previously observed by Robbins et al. (1997) on these plots of a correlation between organic matter, $\mathrm{Zn}$ uptake, and yield in dry bean were not found for wheat. The difference may be related to differences between species, since dry bean is more sensitive to $\mathrm{Zn}$ deficiency than wheat. The confirmation on dry bean that manure treatment increased mycorrhizal colonization and $\mathrm{Zn}$ uptake relative to untreated subsoil was done in pots in the greenhouse (Tarkalson et al., 1998). These observations need field confirmation.

\section{Sweet Corn}

There was no treatment by soil interaction with percent colonization of sweet corn roots, so only the treatment and soil main effects are given (Figure 3). Sweet corn grown on manure-treated soil was less colonized than com grown on untreated soil. Thus, colonization of sweet corn, as with wheat, was decreased with the addition of manure contrary to the results observed in dry bean (Tarkalson et al., 
TABLE 4. Mean corn leaf concentrations of $\mathrm{K}, \mathrm{P}, \mathrm{Mn}, \mathrm{Zn}$, and $\mathrm{Cu}$ and root weight of corn and related statistics by ANOVA as affected by treatment with or without manure and grown in subsoil or topsoil.

\begin{tabular}{|c|c|c|c|c|c|c|c|c|c|}
\hline \multirow[t]{2}{*}{ Parameter } & \multicolumn{3}{|c|}{-.--Treatment $(T)^{1}$} & \multicolumn{3}{|c|}{------Soil (S) ${ }^{1}$} & \multicolumn{3}{|c|}{--Interactions'-- } \\
\hline & Untreated & & Manure & Subsoil & & Topsoil & $T^{*} \mathrm{~S}$ & $\mathrm{~T}^{*} \mathrm{H}^{2}$ & $S^{*} H$ \\
\hline $\bar{K}, \%$ & 2.3 & NS & 2.3 & 2.2 & * & 2.4 & NS & NS & NS \\
\hline $\mathrm{P}, \%$ & 0.36 & NS & 0.40 & 0.39 & NS & 0.37 & NS & NS & NS \\
\hline $\mathrm{Mn}, \mathrm{mg} \mathrm{kg}^{-1}$ & 105 & * & 80 & 87 & NS & 98 & NS & NS & NS \\
\hline $\mathrm{Zn}, \mathrm{mg} \mathrm{kg}^{-1}$ & 50 & * & 38 & 36 & NS & 52 & NS & NS & NS \\
\hline $\mathrm{Cu}, \mathrm{mg} \mathrm{kg}^{-1}$ & 6.5 & NS & 6.3 & 6.2 & NS & 6.7 & NS & NS & NS \\
\hline $\begin{array}{l}\text { Root weight } \\
\text { mg } \mathrm{cm}^{-3}\end{array}$ & 1.2 & NS & 1.1 & 1.1 & NS & 1.2 & NS & NS & NS \\
\hline
\end{tabular}

'NS, *=Not significant at 0.05 and significant at 0.05 probability level, respectively.

${ }^{2} \mathrm{H}$ represents samples harvested on 23 July and 4 Aug.

1998). Contrary to what was seen in wheat, mycorrhizal colonization of sweet com was not affected by subsoil and topsoil fertility differences (Figure 3). Consequently, soil effects on nutrient concentrations of sweet corn are not discussed in detail (Table 3 and 4).

Sweet corn tops had lower $\mathrm{Zn}$ and Mn concentrations in manured compared to unmanured soils (Table 4). Thus, as with wheat, higher mycorrhizal colonization of untreated soils had corresponding higher leaf $\mathrm{Zn}$ and $\mathrm{Mn}$ contents. Root weights in corn were also not affected by treatment. Thus, mycorrhizal colonization in sweet corn resulted in apparent enhanced $\mathrm{Mn}$ and $\mathrm{Zn}$ uptake. The results with $\mathrm{Zn}$ agree with the Kothari et al. (1991) who also showed increased $\mathrm{Zn}$ uptake in mycorrhizal corn plants. But he showed higher colonization of corn decreased $\mathrm{Mn}$ uptake which is opposite our results (Table 4, Figure 3).

Mycorrhizal colonization resulted in increased $\mathrm{Mg}$ and $\mathrm{Ca}$ concentrations in corn leaves harvested on 23 July, but not on 4 Aug. (Table 3). These differences resulted in a treatment by soil interaction for $\mathrm{Mg}$ and $\mathrm{Ca}$. Magnesium concentrations for untreated subsoil was much higher than untreated topsoil, while the manured 
subsoil and topsoil were similar. Calcium concentrations for untreated subsoil and topsoil, and manured topsoil were similar and greater than manured subsoil. There were no significant differences between treatments for $\mathrm{Fe}, \mathrm{Cu}, \mathrm{K}, \mathrm{P}$, and root weight (Table 3 and 4). In our study no increase in $\mathrm{P}, \mathrm{Cu}$, and $\mathrm{K}$ due to mycorrhizal colonization was observed as reported by Srivastava et al. (1996). Sweet corn was not harvested due to confounding effects of severe weed competition.

\section{CONCLUSIONS}

In wheat and sweet corn mycorrhizal colonization was greater in the untreated than manure-treated soils, which also corresponded with increased $\mathrm{Zn}$ and $\mathrm{Mn}$ uptake. Increases in wheat yields were associated with manure additions, but not to mycorrhizal enhanced $\mathrm{Zn}$ uptake. Other nutrients were erratically or not affected by mycorrhizal colonization.

\section{REFERENCES}

AOAC. 1995. Official Method 975.03: Metals in Plants. Official Methods of Analysis of AOAC International. 16th ed. AOAC International, Arlington, VA.

Azcon-Aguilar, C. and J.M. Barea. 1992. Interaction between mycorrhizal fungi and other rhizosphere microorganisms. pp.163-198. In: M.F. Allen (ed.), Mycorrhizal Functioning: An Integrative Fungal Process. 1st ed. Chapman and Hall, Inc., New York, NY.

Brechelt, A. 1987. Wirkung verschiedener organischer Dungemittel auf die effizienz der vamykorrhiza. J. Agron. Crop Sci. 158:280-286.

Burkert, B. and A. Robson. 1994. ${ }^{65} \mathrm{Zn}$ uptake in subterranean clover (Trifolium subterraneum $\mathrm{L}$.) by three vesicular-arbuscular mycorrhizal fungi in a root-free sandy soil. Soil Biol. Biochem. 26:1117-1124.

Buwalda, J.G., D.P. Stribley, and P.B. Tinker. 1985. Vesicular-arbuscular mycorrhizae of winter and spring cereals. J. Agric. Sci. Camb. 105:649-657.

Ellis, J.R., W. Roder, and S.C. Mason. 1992. Grain sorghum-soybean rotation and fertilization influence in vesicular-arbuscular mycorrhizal fungi. Soil Sci. Soc. Am. J. 56:789-794.

Frey, J.E. and J.R. Ellis. 1997. Relationship of soil properties and soil amendments to response of Glomus intraradices and soybeans. Can. J. Bot. 75:483-491.

Giovannetti, M. and B. Mosse. 1980. An evaluation of techniques for measuring vesicular arbuscular mycorrhizal infection in roots. New Phytol. 84:489-500.

Hamilton, M.A., D.T. Westermann, and D.W. James. 1993. Factors affecting zinc uptake in cropping systems. Soil. Sci. Soc. Am. J. 57:1310-1315. 
Hepper, C.M. and A. Warner. 1983. Role of organic matter in growth of a vesiculararbuscular mycorrhizal fungi in soil. Trans. Br. Mycol. Soc. 81:155-156.

Ishac, Y.Z., M.E. El-Haddad, M.J. Daft, E.M. Ramadan, and M.E. El-Demerdash. 1986. Effect of seed inoculation, mycorrhizal infection and organic amendment on wheat growth. Plant Soil 90:373-382.

Kephart, K.D. and J.C. Stark. 1989. Irrigated Spring Wheat Production Guide for Southern Idaho. p. 14. University of Idaho Coop. Ext. Ser. Bull. No. 697.

Kothari, S.K., H. Marschner, and V. Romheld. 1991. Contribution of the VA mycorrhizal hyphae in acquisition of phosphorus and zinc by maize grown in a calcareous soil. Plant Soil 131:177-185.

Lambert, D.H. and T.C. Weidensaul. 1991. Elemental uptake by mycorrhizal soybean from sewage-sludge-treated soil. Soil Sci. Soc. Am. J. 55:393-398.

Makawi, A.A.M. 1982. Local organic manures and their effect on soil microflora and wheat yield. Organic materials and soil productivity in the near east. Food and Agriculture Organization of the United Nations, Rome, Italy.

Menge, J.A. 1983. Utilization of VAM mycorrhizal fungi in agriculture. Can. J. Bot. 61:1015-1024.

Mohammad, M.J., W.L. Pan, and A.C. Kennedy. 1995. Wheat responses to vesiculararbuscular mycorrhizal fungal inoculation of soils from eroded toposequence. Soil Sci. Soc. Am. J. 59:1086-1090.

Mosse, B. 1959. Observations on the extra-matrical mycelium of a vesicular-arbuscular endophyte. Trans. Brit. Mycol. Soc. 42:439-448.

Nicolson, T.H. 1959. Mycorrhiza in the gramineae. 1. Vesicular-arbuscular endophytes, with special reference to the external phase. Trans. Br. Mycol. Soc. 42:421-438.

Robbins, C.W., B.E. Mackey, and L.L. Freeborn. 1997. Improving exposed subsoils with fertilizers and crop rotations. Soil Sci. Soc. Am. J. 61:1221-1225.

SAS Institute. 1989. SAS/STAT User's Guide, pp. 891-996. Version 6. 4th ed. Vol. 2. Statistical Analysis System Institute, Cary, NC.

Sharma, A.K. and P.C. Srivastava. 1991. Effect of vesicular-arbuscular mycorrhizae and zinc application on dry matter and zinc uptake of greengram (Vigna radiata $\mathrm{L}$. Wilczek). Biol. Fert. Soils 11:52-56.

Sharma, A.K., P.C. Srivastava, and B.N. Johri. 1994. Contribution of VA mycorrhiza to zinc uptake in plants. pp. 111-124. In: J.A. Manthey, D.E. Crowley, and D.G. Luster (eds.), Biochemistry of Metal Micronutrients in the Rhizosphere. Lewis Publishers, Boca Raton, FL. 
Shukla, U.C. 1987. Relative response of corn (Zea mays L.), pearl-millet [Pennisetum typhoides, (Burm F.) Stapf and C.E. Hubb], sorghum (Sorghum vulgare), and cowpea [Vigna unguiculata (L.) Walp] to zinc deficiency in soil. J. Plant Nutr. 10:2057-2067.

Singer, M.J. and D.N. Munns. 1987. Soils: An Introduction. Macmillan Publishing Company, New York, NY.

Srivastava, D., R. Kapoor, S.K. Srivastava, and K.J. Mukerji. 1996. Mycorrhizal researchA priority in agriculture. pp. 41-75. In: K.G. Mukerji (ed.), Concepts in Mycorrhizal Research. Kluwer Academic Publishers, Dordrecht, The Netherlands.

St. John, T.V., D.C. Coleman, and C.P.P. Reid. 1983. Association of vesicular-arbuscular mycorrhizal hyphae with soil organic particles. Ecology 64:957-959.

Swaminathan, K. and B.C. Verma. 1979. Responses of three crop species to vesiculararbuscular mycorrhizal infection on zinc-deficient Indian soils. New Phytol. 82:481487.

Tarkalson, D.D., V.D. Jolley, C.W. Robbins, and R.E. Terry. 1998. Mycorrhizal colonization and nutrient uptake of dry bean in manure and composted manure treated subsoil and untreated topsoil and subsoil. J. Plant Nutr. 21:(In review).

Tarkalson, D.D., R.L. Pendleton, V.D. Jolley, C.W. Robbins, and R.E. Terry. 1999. Preparing and staining mycorrhizal structures in dry bean, sweet corn, and wheat using a block digester. Commun. Soil Sci. Plant Anal. 30:(In review).

Tisdale, S.L., M.L. Nelson, J.D. Beaton, and J.L. Havlin. 1993. Soil Fertility and Fertilizers. 5th ed. Macmillan Publishing Company, New York, NY.

Vivekanandan, M. and P.E. Fixen. 1991. Cropping systems effects on mycorrhizal colonization, early growth, and phosphorus uptake of corn. Soil Sci. Soc. Am. J. 55:136-140.

Watanabe, F.S. and S.R. Olsen. 1965. Test of an ascorbic acid method for determining phosphorus in water and $\mathrm{NaHCO}_{3}$ extracts from soils. Soil Sci. Soc. Am. J. Proc. 29:677-678. 